\title{
Litter Decomposition in Semiarid Grassland of Inner Mongolia, China
}

\author{
Ping Liu, ${ }^{1}$ Jianhui Huang, ${ }^{2}$ Xingguo Han, ${ }^{2}$ and Osbert J. Sun ${ }^{3}$
}

Authors are ${ }^{1} \mathrm{PhD}$ Student and ${ }^{2}$ Professors, State Key Laboratory of Vegetation and Environmental Change, Institute of Botany, the Chinese Academy of Sciences, Beijing 100093, People's Republic of China; and ${ }^{3}$ Professor, Key Laboratory for Silviculture and Conservation of Ministry of Education, College of Forest Science, Beijing Forestry University, Beijing 100083, People's Republic of China.

\begin{abstract}
Long-term overgrazing has significantly changed plant species composition in rangeland ecosystems, and this change may alter ecosystem functioning remarkably. In this study, decomposition rates and nutrient dynamics of pure litter (leaf, stem, or root litter) and 11 litter mixtures (from two to five litter components), including nine aboveground litter mixtures and two root litter mixtures, of five common plant species in degraded semiarid rangelands of northern China were studied for $1 \mathrm{yr}$. We found that fine root litters generally decomposed faster and had faster nutrient turnover rates than leaf and stem litters. The decomposition rates of leaves and stems were significantly and positively correlated with initial litter nitrogen $(P<0.01)$ and phosphorus contents $(P<0.05)$, and the decomposition rates of fine roots were significantly and negatively correlated with initial litter carbon:nitrogen ratios $(P<0.05)$. Nonadditive effects were found in six out of the nine aboveground litter mixtures (three positive and three negative). There were only additive effects on decay rates and nutrient fluxes in the two root litter mixtures. The occurrence and direction of nonadditive effects were dependent on the properties of component litters and had no obvious correlations with litter diversity. Negative mixing effects on nutrient immobilization can facilitate the release of some important nutrients during litter decomposition processes, and further help to accelerate nutrient cycling in such semiarid rangeland ecosystems. Our results indicate that change of plant species composition by overgrazing may slow down the mass loss rates, but may not necessarily impact the release of some nutrients.
\end{abstract}

\section{Resumen}

El sobrepastoreo a largo plazo ha cambiado significativamente la composición de las especies del ecosistema del pastizal, y este cambio puede alterar considerablemente la funcionalidad del ecosistema. En este estudio, la tasa de descomposición y la dinámica de los nutrientes de mantillo puro (hojas, tallos, o raíz) y 11 mezclas de mantillo (de dos a 5 componentes de mantillo) incluyendo nueve mezclas de mantillo aéreo y dos mezclas de mantillo de la raíz, de cinco especies de plantas comunes en un pastizal degradado de una zona semiárida del norte de China, fueron estudiados por un año. Encontramos que el mantillo de las raíces finas generalmente se descompone más rápido y tiene una tasa liberación de nutrientes más rápida que el mantillo de hojas y tallos. La tasa de descomposición de hojas y tallos fueron significativa y positivamente correlacionados con el contenido inicial del $\mathrm{N}$ $(P<0.01)$ del mantillo y los contenido de $\mathrm{P}(P<0.05)$, y la tasa de descomposición de las raíces finas fueron significativas pero se correlacionaron negativamente con la relación de $\mathrm{C} / \mathrm{N}(P<0.05)$. Efectos no aditivos fueron encontrados en seis de las nueve mezclas del mantillo aéreo (tres positivas y tres negativas). Existieron únicamente efectos aditivos en las tasas de descomposición y el flujo de nutrientes en dos mezclas del mantillo de la raíz. La incidencia y la dirección de los efectos no-aditivos dependieron de las propiedades de los componentes del mantillo y no existió una clara correlación con la diversidad del mantillo. Los efectos negativos en la inmovilización de nutrientes puede facilitar la liberación de algunos nutrientes importantes durante el proceso de descomposición del mantillo y ayuda adicional para acelerar el ciclo de nutrientes en tal ecosistema semiárido. Nuestros resultados indican que los cambios en la composición de las especies debido al sobrepastoreo quizá disminuya la mas de la liberación de nutrientes pero quizá no necesariamente tenga un impacto en la liberación de algunos nutrientes.

Key Words: grassland ecosystem, mixture effects, nutrient dynamics, nutrient release, typical steppe

\section{INTRODUCTION}

With ever-increasing stocking rates in northern China rangelands since 1980s, grassland communities have undergone significant change, not only in the abundance of different species but also in dominant species replacement (Carrera et al. 2008). For example,

Research was jointly funded by the State Key Basic Research Development Program of China, the Ministry of Science and Technology (2007CB106801) and a grant from the National Natural Science Foundation of China (30821062).

Correspondence: Jianhui Huang, State Key Laboratory of Vegetation and Environmental Change, Institute of Botany, the Chinese Academy of Sciences, Beijing 100093, People's Republic of China. Email: jhhuang@ibcas.ac.cn

Current address: Ping Liu, Soil and Fertilizer Institute, Shandong Academy of Agricultural Sciences, Jinan 250100, Shandong, People's Republic of China.

Manuscript received 3 March 2008; manuscript accepted 14 March 2009. a Stipa krylovii Roshev- or Leymus chinensis (Trin) Tzveldominated rangeland may become Artemisia frigida Willd.dominated, perhaps with the appearance of some Allium species, after being exposed to long-term overgrazing ( $\mathrm{Li} 1989$ ). The change of plant species composition may alter ecosystem functions such as the litter decomposition process through interaction between different plant species, and may subsequently impact nutrient cycling in these rangeland ecosystems (Vivanco and Austin 2006). Transfer of nutrients or other chemicals may occur among different litter types (Hättenschwiler et al. 2005), causing nonadditive effects, which are generally defined as the deviation of litter mixture decomposition rates from the predicted values based on each component species (type) in the litter mixture. Such nonadditive effects could be either facilitative or antagonistic to ecosystem functioning. 
Previous studies indicate that nutrient immobilization and mineralization patterns have usually been altered with litter mixing (Blair et al. 1990; Briones and Ineson 1996; McTiernan et al. 1997; Conn and Dighton 2000). Among studies that showed nonadditive nutrient dynamics and decomposition rates, most of them increased net nitrogen $(\mathrm{N})$ mineralization in mixtures compared with the predicted values from singlelitter decomposition (Gartner and Cardon 2004). Litter mixing may have absolutely different effects on decay rates and on nutrient dynamics during the course of decomposition (Ball et al. 2008). Overall, it is difficult to make general conclusions about litter mixing effects, and the directions of these effects (either positive or negative).

Most studies have paid more attention to aboveground litter decomposition whereas many fewer have addressed (fine) root decomposition (Robinson et al. 1999; Gartner and Cardon 2004), although fine root mortality and decomposition can be significant to global carbon budgeting and nutrient availability in the soil, especially in ecosystems with high belowground allocation such as arid or semiarid rangelands (Gijsman et al. 1997; Silver and Miya. 2001). In addition, most studies to date have included two or three species and compared monocultures with just one mixing treatment. More studies are needed to help elucidate general patterns of nutrient release and decomposition of litter mixtures and underlying mechanisms to explain nonadditive effects.

In this study, we selected five dominant plant species in a degraded typical steppe after long-term overgrazing in northern China, and studied the decay rate and nutrient dynamics of 10 pure litter types (leaf, stem, or root) and 11 possible litter mixture combinations (from two to five litter species or plant organs) that exist in a real decomposition environment, including nine aboveground litter mixtures and two fine root litter mixtures for $1 \mathrm{yr}$. We hypothesized that 1) litter mixing effects on decay rates and nutrient release would occur in this system among dominant species and newly abundant species and 2) the effects would increase with increasing litter species diversity, as most biodiversity and ecosystem functioning studies have indicated (Tilman and Downing 1994; Hooper and Vitousek 1997).

\section{MATERIALS AND METHODS}

\section{Study Site}

Our study was conducted in the Duolun Restoration Ecology Research Station in Inner Mongolia, China. The field site, with a total area of around $100 \mathrm{ha}$, is located at lat $42^{\circ} 02^{\prime} \mathrm{N}$, long $116^{\circ} 16^{\prime} \mathrm{E}$ with an elevation of $1300 \mathrm{~m}$ above sea level. The area is typical of semiarid temperate and continental climate with long-term mean annual precipitation of $\sim 380 \mathrm{~mm}$; mean annual, minimum, and maximum air temperatures of $1.6^{\circ} \mathrm{C}$, $-18.3^{\circ} \mathrm{C}$, and $18.7^{\circ} \mathrm{C}$, respectively. Most of the precipitation (about $60-70 \%$ ) occurs in July and August. Soils of the region are commonly known as chestnut (Food and Agriculture Organization of the United Nations 2006), with low nutrientand water-holding capacity. The surface $10-\mathrm{cm}$ soil layer is slightly alkaline $(\mathrm{pH}=7.2)$ and contains $20.4 \mathrm{~g} \cdot \mathrm{kg}^{-1}$ total carbon (C), $1.63 \mathrm{~g} \cdot \mathrm{kg}^{-1}$ total $\mathrm{N}$ (with available $\mathrm{N}$ at $\left.10.35 \mathrm{mg} \cdot \mathrm{kg}^{-1}\right)$, and $0.31 \mathrm{~g} \cdot \mathrm{kg}^{-1}$ total phosphorus $(\mathrm{P})$. The soil bulk density is about $1.3 \mathrm{~g} \cdot \mathrm{cm}^{-3}$.
The primary vegetation of this area is that of the typical steppe, which is characterized by the dominance of grass species such as Stipa krylovii and Leymus chinensis. Other abundant plant species include Cleistogenes squarrosa (Trin.) Keng, Agropyron cristatum (L.) Gaertn, Artemisia frigida Willd., Potentilla acaulis L., and Carex duriuscula C. A. Mey. After long-term overgrazing, the species composition has changed markedly, with a reduction in the dominance of $L$. chinensis, and appearance of some Allium species. The five plant species we selected in this study, including three bunch grasses (S. krylovii, C. squarrosa, and A. cristatum) and two perennial forbs (Allium bidentatum Fisch. ex Prokh. and Allium ramosum L.) are dominant or abundant plant species of the current typical steppe, with Stipa krylovii being the constructive species of the community.

\section{Litter Preparation and Experimental Design}

In late October, 2004, fresh leaf litters of S. krylovii ( $\left.\mathrm{L}_{\mathrm{SK}}\right)$, C. squarrosa $\left(\mathrm{L}_{\mathrm{CS}}\right)$, and $A$. bidentatum $\left(\mathrm{L}_{\mathrm{AB}}\right)$ and fresh stem litters of A. bidentatum $\left(\mathrm{S}_{\mathrm{AB}}\right)$, S. kryloii $\left(\mathrm{S}_{\mathrm{SK}}\right)$, A. ramosum $\left(\mathrm{S}_{\mathrm{AR}}\right)$, and A. cristatum $\left(\mathrm{S}_{\mathrm{AC}}\right)$ were randomly collected over the whole study site (see Table 1 for the list). By carefully observing litter color, current-year litters, including freshly fallen and senesced tissues still attached to the plants could be distinguished easily. Roots of $S$. krylovii $\left(\mathrm{R}_{\mathrm{SK}}\right)$, C. squarrosa $\left(\mathrm{R}_{\mathrm{CS}}\right)$, and A. cristatum $\left(\mathrm{R}_{\mathrm{AC}}\right)$ were collected with a shovel in the surface soil layer within the depth of $15 \mathrm{~cm}$, in which the majority of fine roots are distributed. They were carefully washed to remove the adhering soil particles and organic debris. Only fine roots $(<1 \mathrm{~mm}$ diameter) were used for the decomposition experiment. Both aboveground litters (leaves and stems) and belowground litters (fine roots) were air-dried at room temperature to constant mass. Five subsamples for each airdried litter type were oven-dried at $70^{\circ} \mathrm{C}$ for 48 h to determine the water contents of the air-dried litters. The percentage of water was used to determine the initial dry mass in each litterbag.

Air-dried litters were clipped into fragments of $5-10 \mathrm{~cm}$ in length, and placed into $10 \times 15 \mathrm{~cm}$ polyethylene litterbags (mesh size, $1 \mathrm{~mm}^{2}$ ) individually or according to the combinations and mass ratios listed in Table 2. Aboveground litterbags contained $3 \mathrm{~g}$ of litter (oven-dried basis) in each bag, whereas belowground litterbags contained $2 \mathrm{~g}$ of fine root litter (ovendried basis) in each bag. For litter mixtures, we generally used a 1:1 mass ratio between constitutional litter types in a specific litter mixture. However, considering possible difference in the abundance of those species or litter types in the community, we also chose four two-litter mixtures using a 2:1 mass ratio. The amount of each litter type used in a litter mixture mostly depended on the availability of those litters in the community at the time we collected the litter samples. We mixed litters thoroughly before putting them into the litterbags.

Litter decomposition was determined under field conditions in a randomized block design with five replicates in a fertilization experiment site with total area of 2 ha, and only nonfertilized blocks were used in this study. Each block had an area of $10 \times 15 \mathrm{~m}$. On 1 November 2004, 28 litterbags for seven aboveground pure litter types and 36 litterbags for nine aboveground litter mixture combinations were randomly 
distributed at each block and fixed onto the soil surface by small wire hooks to ensure full contact of the litterbags with the soil surface and to prevent the bags from being blown away by strong winds. Four litterbags for each kind of litter were placed along a line with a distance about $50 \mathrm{~cm}$, and thus they could be found and retrieved easily after a period of decomposition. Twelve litterbags for three pure root types and eight litterbags for two root-mixture combinations were connected together with string by the same grouping methods as the aboveground litterbags and arranged at least $50 \mathrm{~cm}$ apart before being inserted into the soil on each of the five replicate blocks. To bury the litterbags, we sliced down through the soil at a $45^{\circ}$ angle to a depth of about $15 \mathrm{~cm}$ and then slipped the bags into the incision. The narrow incision ensured good contact of the litterbags with soil and minimal soil disturbance. A total of 420 litterbags were settled in this study ( 21 mixtures $\times 4$ sampling dates $\times 5$ blocks).

Sets of litterbags were retrieved $6,8,10$, and 12 mo after initial deployment. For each sampling time, one litterbag for each litter type (pure or mixture) was collected from each block. In the laboratory, extraneous matter such as other plant materials, rocks, and small animals were handpicked from the litterbags. The fine-root litterbags were carefully cleaned to remove the adhering soil particles. Other endogenously derived materials, such as roots growing into the litterbags during decomposition processes, were also removed. The retrieved litters were then oven-dried at $70^{\circ} \mathrm{C}$ for $48 \mathrm{~h}$ to determine the remaining dry mass.

\section{Chemical Analysis of Litters}

For initial litter chemistry, total $\mathrm{C}$ and lignin along with six other nutrients $(\mathrm{N}, \mathrm{P}$, potassium $[\mathrm{K}]$, sodium $[\mathrm{Na}]$, calcium $[\mathrm{Ca}]$, and magnesium $[\mathrm{Mg}]$ ) were determined in all five replicates. For other litter samples harvested during decomposition, after determination of the oven-dried mass, only three replicated litters from the five replicate blocks were chosen randomly for further chemical analysis $(\mathrm{N}, \mathrm{P}, \mathrm{K}, \mathrm{Na}, \mathrm{Ca}, \mathrm{Mg})$ because we found the variation was small enough for those initial litter chemistries among the five replicated subsamples. We selected these six nutrient elements because they were macronutrients, were essential for plant growth, and were widely investigated in previous studies. Samples were ground to pass through a 4-mesh screen in the laboratory. Total $\mathrm{N}$ was determined by the Kjeldahl acid-digestion method with an Alpkem autoanalyzer (Kjektec System 1026 distilling unit, Foss, Hoganas, Sweden). After subsamples were digested in $\mathrm{HCLO}_{4}+\mathrm{HNO}_{3}$ (for $\mathrm{K}, \mathrm{Na}, \mathrm{Ca}, \mathrm{Mg}$ ) or $\mathrm{H}_{2} \mathrm{SO}_{4}+\mathrm{H}_{2} \mathrm{O}_{2}$ (for $\mathrm{P}$ ), total $\mathrm{P}$ was determined by molybdenum blue colorimetric method with an ultraviolet-visible spectrophotometer (UV2550; Shimadzu, Suzhou, People's Republic of China). K and $\mathrm{Na}$ were analyzed through a flame-photometric procedure, and $\mathrm{Ca}$ and $\mathrm{Mg}$ using an acetylene-oxygen flame and with 5\% $\mathrm{LaCl}_{3}$ as a releasing agent with an atomic absorption spectrometer (5100PC; Perkin Elmer, Waltham, MA). Total $\mathrm{C}$ was measured by wet-combustion method (Nelson and Sommers 1996) and lignin was determined as Klason lignin by the method of Effland (1977). All above-mentioned chemical analyses were performed in the laboratory for chemical analysis in the State Key Laboratory of Vegetation and Environmental Change, Institute of Botany, the Chinese Academy of Sciences. 
Table 2. Mean (1 SE) initial nutrient contents, and mean (1 SE) observed and expected decay constants $(k)$ of 11 litter mixture combinations in the typical steppe of Inner Mongolia, China $(n=5)$. The Arabic numeral "2" before a litter type in the litter mixture combinations column denotes that two times the mass of that litter type was included in the mixture. The direction of mixing effects are shown with plus sign (+) indicating positive effects, minus sign (-) indicating negative effects, and "No" indicating no effects. ${ }^{1}$

\begin{tabular}{|c|c|c|c|c|c|c|c|c|c|}
\hline \multirow{2}{*}{$\begin{array}{l}\text { Litter mixture } \\
\text { combinations }\end{array}$} & \multirow[b]{2}{*}{$\mathrm{N}\left(\mathrm{mg} \cdot \mathrm{g}^{-1}\right)$} & \multirow[b]{2}{*}{$P\left(m g \cdot g^{-1}\right)$} & \multirow[b]{2}{*}{$\mathrm{K}\left(\mathrm{mg} \cdot \mathrm{g}^{-1}\right)$} & \multirow[b]{2}{*}{$\mathrm{Na}\left(\mathrm{mg} \cdot \mathrm{g}^{-1}\right)$} & \multirow[b]{2}{*}{$\mathrm{Ca}\left(\mathrm{mg} \cdot \mathrm{g}^{-1}\right)$} & \multirow[b]{2}{*}{$\operatorname{Mg}\left(\mathrm{mg} \cdot \mathrm{g}^{-1}\right)$} & \multicolumn{2}{|c|}{$k\left(\cdot \mathrm{yr}^{-1}\right)$} & \multirow{2}{*}{$\begin{array}{l}\text { Mixing } \\
\text { effects }\end{array}$} \\
\hline & & & & & & & Observed & Expected $^{2}$ & \\
\hline $2 \mathrm{~L}_{\mathrm{SK}}-\mathrm{S}_{\mathrm{SK}}$ & $2.57(0.11)$ & $0.46(0.02)$ & $2.73(0.10)$ & $0.97(0.02)$ & $2.10(0.16)$ & $0.28(0.02)$ & $0.39(0.02)$ & $0.29(0.01)^{\star * *}$ & + \\
\hline $2 \mathrm{~L}_{\mathrm{SK}}-\mathrm{S}_{\mathrm{AC}}$ & $2.50(0.15)$ & $0.42(0.03)$ & $2.63(0.11)$ & $1.19(0.04)$ & $2.20(0.20)$ & $0.28(0.02)$ & $0.36(0.02)$ & $0.28(0.01)^{\star * *}$ & + \\
\hline $2 \mathrm{~L}_{\mathrm{AB}}-\mathrm{S}_{\mathrm{AB}}$ & $2.60(0.18)$ & $0.51(0.02)$ & $3.13(0.17)$ & $0.27(0.02)$ & $5.90(0.23)$ & $0.58(0.02)$ & $0.49(0.02)$ & $0.39(0.02)^{\star * *}$ & + \\
\hline $2 \mathrm{~L}_{\mathrm{AB}}-\mathrm{S}_{\mathrm{AR}}$ & $2.47(0.18)$ & $0.45(0.02)$ & $2.27(0.15)$ & $0.34(0.04)$ & $5.77(0.19)$ & $0.64(0.04)$ & $0.39(0.03)$ & $0.38(0.02)$ & No \\
\hline $\mathrm{R}_{\mathrm{SK}}-\mathrm{R}_{\mathrm{CS}}$ & $6.05(0.23)$ & $0.99(0.04)$ & $2.95(0.08)$ & $0.76(0.03)$ & $3.00(0.17)$ & $0.52(0.03)$ & $0.47(0.03)$ & $0.47(0.02)$ & No \\
\hline $\mathrm{R}_{\mathrm{AC}}-\mathrm{R}_{\mathrm{CS}}$ & $4.35(0.13)$ & $1.17(0.05)$ & $2.55(0.16)$ & $0.72(0.02)$ & $1.90(0.22)$ & $0.34(0.02)$ & $0.42(0.02)$ & $0.43(0.01)$ & No \\
\hline $\mathrm{L}_{\mathrm{CS}}-\mathrm{S}_{\mathrm{AB}}-\mathrm{S}_{\mathrm{SK}}$ & $2.10(0.08)$ & $0.47(0.01)$ & $3.03(0.10)$ & $0.42(0.02)$ & $2.57(0.10)$ & $0.38(0.01)$ & $0.28(0.02)$ & $0.28(0.00)$ & No \\
\hline $\mathrm{L}_{A B}-S_{A B}-S_{A C}$ & $2.13(0.07)$ & $0.43(0.02)$ & $3.17(0.14)$ & $0.57(0.05)$ & $4.20(0.20)$ & $0.43(0.01)$ & $0.28(0.01)$ & $0.31(0.01)^{\star *}$ & - \\
\hline $\mathrm{L}_{S K}-\mathrm{L}_{\mathrm{AB}}-\mathrm{S}_{\mathrm{SK}}-\mathrm{S}_{\mathrm{AC}}$ & $2.40(0.08)$ & $0.42(0.01)$ & $2.73(0.14)$ & $0.76(0.03)$ & $3.15(0.13)$ & $0.35(0.00)$ & $0.31(0.02)$ & $0.31(0.01)$ & No \\
\hline $\mathrm{L}_{\mathrm{CS}}-\mathrm{S}_{\mathrm{AB}}-\mathrm{S}_{\mathrm{SK}}-\mathrm{S}_{\mathrm{AC}}$ & $2.00(0.06)$ & $0.42(0.02)$ & $2.95(0.11)$ & $0.60(0.04)$ & $2.38(0.13)$ & $0.34(0.01)$ & $0.23(0.01)$ & $0.26(0.00)^{\star * *}$ & - \\
\hline $\mathrm{L}_{\mathrm{CS}}-\mathrm{L}_{\mathrm{AB}}-\mathrm{S}_{\mathrm{SK}}-\mathrm{S}_{\mathrm{AR}}-\mathrm{S}_{\mathrm{AC}}$ & $2.14(0.05)$ & $0.41(0.02)$ & $2.36(0.09)$ & $0.56(0.04)$ & $3.20(0.09)$ & $0.44(0.01)$ & $0.26(0.01)$ & $0.29(0.01)^{\star \star \star}$ & - \\
\hline
\end{tabular}

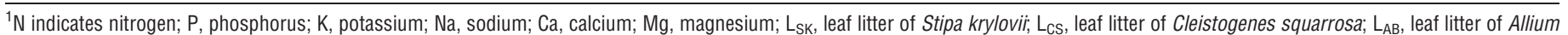

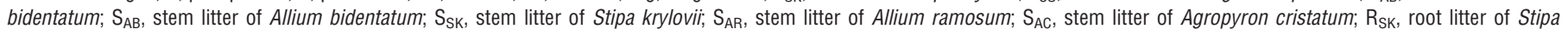
krylovii; $\mathrm{R}_{\mathrm{CS}}$, root litter of Cleistogenes squarrosa; and $\mathrm{R}_{\mathrm{AC}}$, root litter of Agropyron cristatum.

${ }^{2}$ Asterisks indicate significant differences between the observed and expected decay constants. ${ }^{\star} P<0.05 ;{ }^{* \star} P<0.01 ;{ }^{\star \star \star} P<0.001$.

\section{Data Analysis}

The value of decay constant, $k$, was determined by fitting the following exponential function (Olson 1963):

$$
x_{t} / x_{0}=\mathrm{e}^{-k t}
$$

where $x_{t}$ is the remaining litter mass after a given time period $t$ and $x_{o}$ the initial litter mass. The remaining litter nutrients were calculated by multiplying the remaining sample mass by the respective nutrient concentrations. Percentage of mass and nutrient remaining from singlespecies litterbags in each replicate block were combined to calculate expected percentage of mass and nutrient remaining for litter mixtures according to their initial mass ratio in the mixture. For example, the expected remaining percentage of mass for the combination $2 \mathrm{~L}_{\mathrm{SK}}-\mathrm{S}_{\mathrm{SK}}$, the two litter types mixed in a 2:1 mass ratio, in a plot on a given sample date was calculated as the following:

$$
\begin{aligned}
& \text { Expected mixture } 2 \mathrm{~L}_{\mathrm{SK}}-\mathrm{S}_{\mathrm{SK}} \\
& =\left(2 \text { observed pure } \mathrm{L}_{\mathrm{SK}}+\text { observed pure } \mathrm{S}_{\mathrm{SK}}\right) / 3 .
\end{aligned}
$$

The values from each block then were averaged by date ( $n=5$ for mass and $n=3$ for nutrient element) to calculate the mean and standard errors of expected percentage of mass or nutrient remaining. Expected decay constant $k$ for litter mixtures was calculated based on their expected mass remaining over time in each individual block $(n=5)$.

Bivariate correlations were performed to determine the relationship between decomposition rate and the initial litter chemistry of pure litter types. Tests of significance of the decay constant and remaining mass and nutrients on each sampling date between observed and expected values were performed by 1-way analysis of variance using procedures of SPSS (v. 13.0) with confidence level of $P<0.05$.

\section{RESULTS}

\section{Initial Litter Chemistry}

Fine roots of S. krylovii, C. squarrosa, and A. cristatum had the highest initial N, P, and lignin and the lowest C:N and C:P ratios (Table 1). Stems of A. bidentatum, S. krylovii, A. ramosum, and $A$. cristatum had the lowest initial $\mathrm{N}, \mathrm{P}$, and lignin and the highest C:N and C:P ratios. The values of these variables for leaf litters of S. krylovii, C. squarrosa, and A. bidentatum fell in between those for roots and stems.

\section{Decay Rates}

During the first 6 mo, there was less than $10 \%$ mass loss for all the 10 litter types. From then on, mass losses increased gradually and were greatest from the sixth to eighth months (i.e., from June 2005 to August 2005). By the end of first-year decomposition, the percentage of mass remaining for roots, leaves, and stems was about $55 \%, 65 \%$, and $75 \%$, respectively. Overall, fine root litters had the highest decay constants, and ranked with other tissue types as roots $>$ leaves $>$ stems except for $R_{C S}$, of which the decay constant was lower than that of $\mathrm{L}_{\mathrm{AB}}$ (Table 1). Correlation analysis showed that the decomposition rates of leaves and stems were positively correlated with initial litter $\mathrm{N}(r=0.94, n=35$, $P=0.001)$ and $\mathrm{P}$ concentrations $(r=0.88, n=35, P=0.010)$. The decomposition rates of fine roots were negatively correlated with the initial litter C:N ratios $(r=-0.70, n=15, P=0.040)$. Significant linear regression was found with all litter types between litter decay constants and litter initial lignin: $\mathrm{N}$ ratio $(r=-0.72, n=50, P=0.018)$.

For the nine aboveground litter mixture combinations, three of the four leaf-shoot mixtures with a 2:1 mass ratio, i.e., $2 \mathrm{~L}_{\mathrm{SK}}-\mathrm{S}_{\mathrm{SK}}$, $2 \mathrm{~L}_{\mathrm{SK}}-\mathrm{S}_{\mathrm{AC}}$, and $2 \mathrm{~L}_{\mathrm{AB}}-\mathrm{S}_{\mathrm{AB}}$, had significantly higher observed decay 
constants than their expected values $(P<0.001$; Table 2$)$. To the contrary, in litter mixtures that had leaf:shoot mass ratios of 1:2, $1: 3$, or 2:3, i.e., $\mathrm{L}_{\mathrm{AB}}-\mathrm{S}_{\mathrm{AB}}-\mathrm{S}_{\mathrm{AC}}, \mathrm{L}_{\mathrm{CS}}-\mathrm{S}_{\mathrm{AB}}-\mathrm{S}_{\mathrm{SK}}-\mathrm{S}_{\mathrm{AC}}$, and $\mathrm{L}_{\mathrm{CS}}-\mathrm{L}_{\mathrm{AB}}-$ $\mathrm{S}_{\mathrm{SK}}-\mathrm{S}_{\mathrm{AR}}-\mathrm{S}_{\mathrm{AC}}$, the observed decay constants were significantly, but slightly, lower than those of the expected values $(P<0.01)$. The other three aboveground mixtures, i.e., $2 \mathrm{~L}_{\mathrm{AB}}-\mathrm{S}_{\mathrm{AR}}, \mathrm{L}_{\mathrm{CS}}-\mathrm{S}_{\mathrm{AB}}-$ $\mathrm{S}_{\mathrm{SK}}$, and $\mathrm{L}_{\mathrm{SK}}-\mathrm{L}_{\mathrm{AB}}-\mathrm{S}_{\mathrm{SK}}-\mathrm{S}_{\mathrm{AC}}$, and the two fine root litter mixtures, $\mathrm{R}_{\mathrm{SK}}-\mathrm{R}_{\mathrm{CS}}$ and $\mathrm{R}_{\mathrm{AC}}-\mathrm{R}_{\mathrm{CS}}$, did not show any significant difference between the observed and expected decay constants.

\section{Nutrient Dynamics}

Overall, fine root litters displayed remarkably different patterns of nutrient dynamics from those of leaf and stem litters during the first-year decomposition (Figs. 1 and 2). For $\mathrm{N}$ and $\mathrm{P}$, there was a slight decrease for all the leaf and stem litters during the first $6 \mathrm{mo}$, but immobilization occurred thereafter and lasted until the end of this study (Fig. 1). On the contrary, the three fine-root litters immobilized large amounts of $\mathrm{N}$ during the first $6 \mathrm{mo}$ and released $\mathrm{N}$ thereafter, but did not show any immobilization of $\mathrm{P}$ during the entire period of the decomposition (Fig. 2). The three fine-root litters released about $20 \% \mathrm{~N}$ and $30 \% \mathrm{P}$ by the end of $1 \mathrm{yr}$ of decomposition.

Root litter steadily released $\mathrm{K}$ and $\mathrm{Na}$ during the first 10 mo of decomposition, which was similar to the patterns for leaf and stem litters (Figs. 1 and 2). However, the three root litters immobilized about $5-10 \% \mathrm{~K}$ and $\mathrm{Na}$ in the last 2 mo, whereas leaf and stem litter showed no immobilization at all (Figs. 1 and 2). The release of $\mathrm{Na}$ from all of the seven aboveground litter types was close to that of $\mathrm{K}$ after $1 \mathrm{yr}$ (Fig. 1) whereas from root litter types, this release was slightly higher.

The dynamics of $\mathrm{Ca}$ and $\mathrm{Mg}$ for the fine-root litters during the first-year decomposition were similar to those of $\mathrm{K}$ and $\mathrm{Na}$ (Fig. 2), whereas aboveground litters generally showed an early immobilization followed by a release of $\mathrm{Ca}$ (Fig. 1). The leaf litter of $A$. bidentatum released $\mathrm{Ca}$ during the whole study period. After $1 \mathrm{yr}$ of decomposition, the leaf litter of S. krylovii and A. bidentatum and stem litter of $A$. bidentatum and A. ramosum showed a net release of $\mathrm{Ca}$. The dynamics of $\mathrm{Mg}$ in aboveground litter were somewhat more complex than those of $\mathrm{Ca}$, and there was a striking difference among litter types (Fig. 1). The leaf litter of S. krylovii and stem litter of A. bidentatum, S. krylovii, and A. cristatum immobilized large amounts of $\mathrm{Mg}$ in a fluctuating manner. The leaf litter of C. squarrosa and A. bidentatum released $\mathrm{Mg}$ during almost the whole study period. The stem litter of $A$. ramosum showed an approximately similar pattern of $\mathrm{Mg}$ dynamics to the three root-litter types (Figs. 1 and 2).

Initial litter nutrient contents $(\mathrm{N}, \mathrm{P}, \mathrm{K}, \mathrm{Na}, \mathrm{Ca}$, and $\mathrm{Mg}$ ) of the 11 litter mixture combinations were calculated based on the individual litter species constituted in the mixture (Table 2). Any significant deviation between observed and expected values during decomposition represents a mixing effect (Chapman et al. 1988; Blair et al. 1990). For the two fine-root litter mixtures and three aboveground litter mixtures that showed no mixing effects on their decay rates, the mixing did not show any interactive effects on the nutrient dynamics either during the 1-yr study $(P>0.05)$. Similar patterns were observed for N, P, Ca, and Mg fluxes of the remaining six litter mixtures regardless of the directions of the interactive effects on decay rates (either positive or negative). We compared the measured values of $\mathrm{N}, \mathrm{P}, \mathrm{Ca}$, and
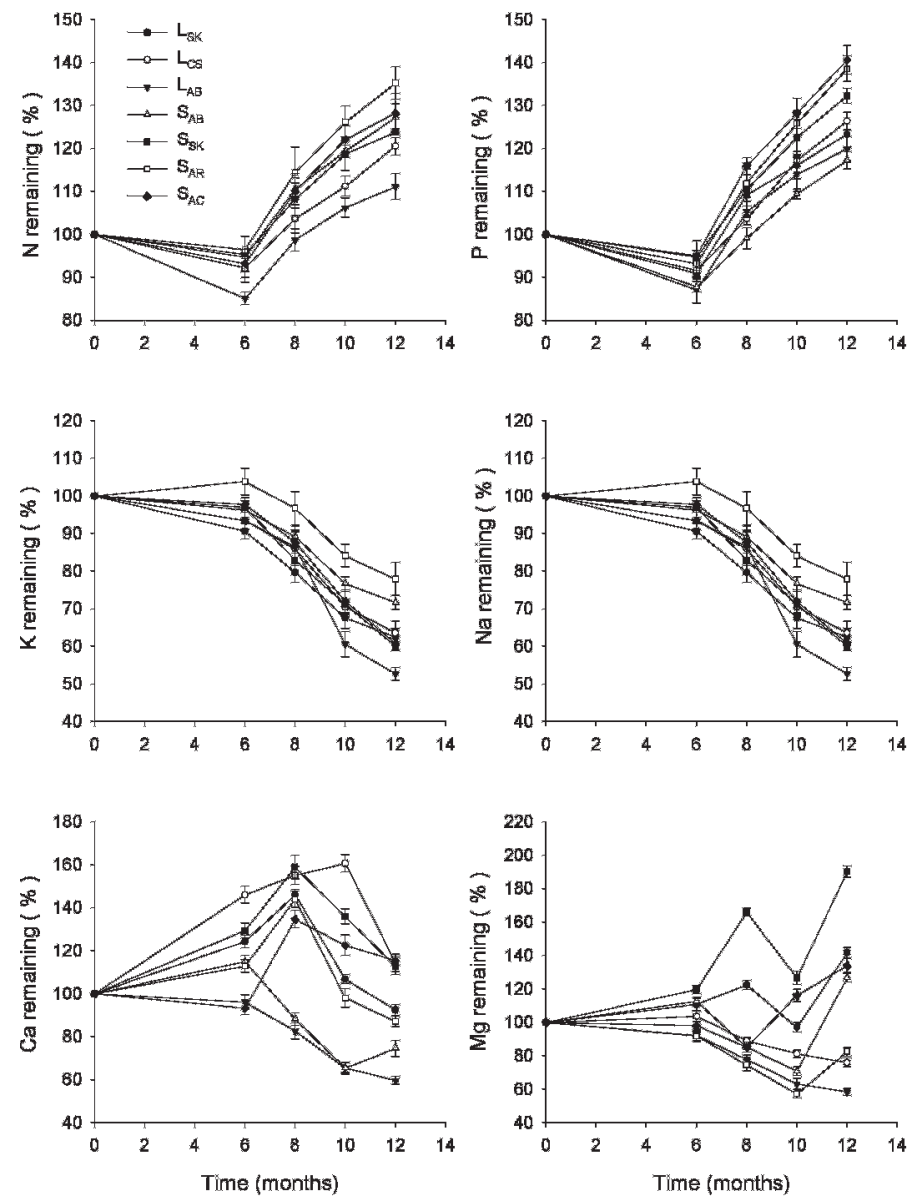

Figure 1. Changes in absolute amount of nitrogen $(\mathrm{N})$, phosphorus $(\mathrm{P})$, potassium $(\mathrm{K})$, sodium $(\mathrm{Na})$, calcium $(\mathrm{Ca})$, and magnesium $(\mathrm{Mg})$ during 12 mo of decomposition for pure leaf and stem litters. The Arabic numeral " 2 " before a litter type in the litter mixture combinations column denotes that two times the mass of that litter type was included in the mixture. Vertical bars represent standard errors $(n=3)$. Species and litter codes are presented in Table 1.

$\mathrm{Mg}$ with the expected values for different litter mixtures. The early releases of $\mathrm{N}$ and $\mathrm{P}$ of the above six mixture combinations were greater, although not statistically significant, and following immobilization was lower than expected (Figs. 3 and 4). The early immobilization and the following release of $\mathrm{Ca}$ were both lower than expected (Fig. 5). As for Mg, the mixture combination of $2 \mathrm{~L}_{\mathrm{AB}}-\mathrm{S}_{\mathrm{AB}}$ showed significantly greater net release than expected, whereas the other five combinations showed significantly lower net immobilization than expected, but all six showed an increasing tendency of immobilization by the end of the first year of decomposition (Fig. 6). However, there were no significant differences in the release of $\mathrm{K}$ and $\mathrm{Na}$ between expected and observed values for all litter mixtures regardless of whether significant nonadditive effects occurred in mass loss rates, and regardless of the directions of those effects.

\section{DISCUSSION}

When litter decomposed individually, our results indicated that decomposition in these arid or semiarid rangeland ecosystems 

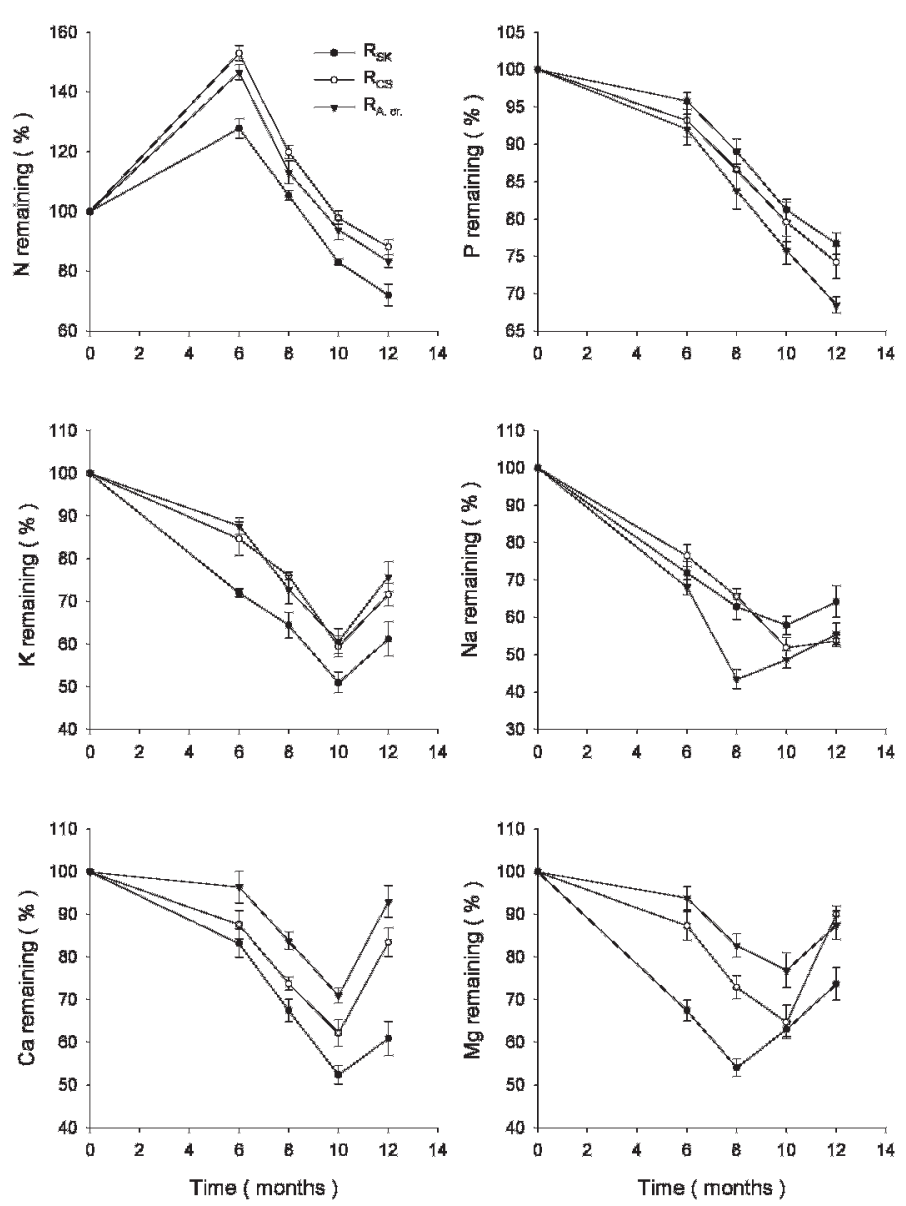

Figure 2. Changes in absolute amount of nitrogen $(N)$, phosphorus $(P)$, potassium $(\mathrm{K})$, sodium $(\mathrm{Na})$, calcium $(\mathrm{Ca})$, and magnesium $(\mathrm{Mg})$ during 12 mo of decomposition for pure root litter. Vertical bars represent standard errors $(n=3)$. The Arabic numeral " 2 " before a litter type in the litter mixture combinations column denotes that two times the mass of that litter type was included in the mixture. Species and litter codes are presented in Table 1.

was strongly controlled by initial litter quality, designated either by $\mathrm{N}$ and $\mathrm{P}$ contents or C:N and lignin: $\mathrm{N}$ ratios, which was in agreement with the results reported by some previous studies (Meentemeyer 1978; Aerts 1997; Moretto et al. 2001; Liu et al. 2007). Moreover, decomposition of the aboveground leaf and stem litters seems to be better explained by initial $\mathrm{N}$ and $\mathrm{P}$ contents whereas the decomposition of fine root litters is best explained by initial C: $\mathrm{N}$ and lignin: $\mathrm{N}$ ratios. Differences in the decomposition environment for aboveground and belowground litters may explain this difference because microbes belowground can more easily access additional $\mathrm{N}$ and $\mathrm{P}$ needed for decomposition. Thus, belowground decomposition may be influenced more by initial $\mathrm{C}$ or $\mathrm{C}$ combined with $\mathrm{N}$ rather than initial $\mathrm{N}$ and/or P contents.

Similar to the findings in some previous studies (Seastedt 1988; Seastedt et al. 1992; Hobbie 1996), we also found that decomposition of root litters was much faster than most of the aboveground leaf and stem litters, most likely because the root litters had much higher initial litter $\mathrm{N}$ and $\mathrm{P}$ contents and lower lignin: $\mathrm{N}$ ratios than the leaf and stem litters. In a previous study, we found that differences in $\mathrm{N}$ and $\mathrm{P}$ contents of decomposing litters were closely related to the differences in the
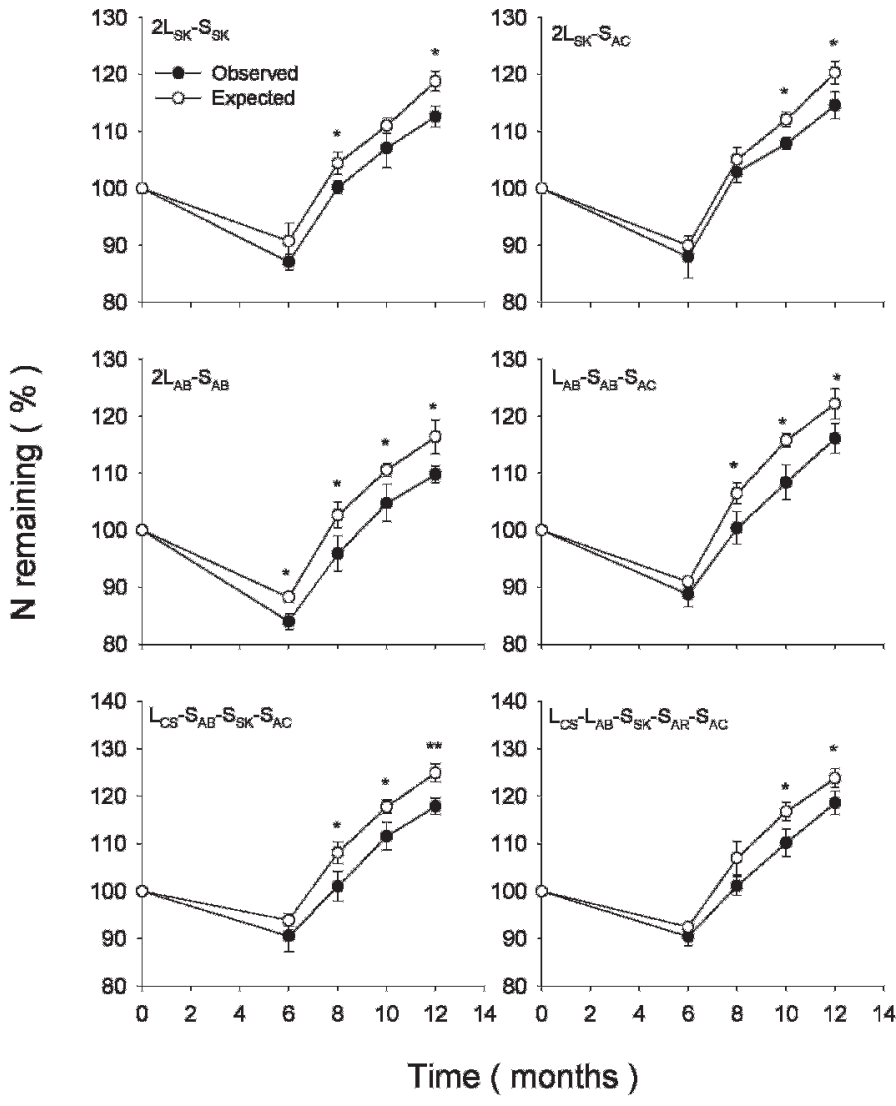

Figure 3. Comparisons of observed percentage of nitrogen $(\mathrm{N})$ remaining in litter mixtures over time with expected percentage of $\mathrm{N}$ remaining calculated from component pure litters. Vertical bars represent standard errors $(n=3)$. The Arabic numeral " 2 " before a litter type in the litter mixture combinations column denotes that two times the mass of that litter type was included in the mixture. Asterisks indicate significant differences between observed and expected values: ${ }^{*} P<0.05 ;{ }^{*} P<0.01$; ${ }^{* * *} P<0.001$. Species and litter codes are presented in Table 1.

rate of decomposition between two plant species at the same study site (Liu et al. 2006). Another possible reason for the faster decomposition of root litters might be the different decay environments between them. The roots were buried in the soil, and thus experienced higher moisture conditions, richer microbial communities, and closer proximity to mineralized nutrients than leaves and stems placed aboveground (Ostertag and Hobbie 1999). However, lower fine-root decomposition rates were also found in earlier studies because of higher content of lignin (Gholz et al. 2000; Vivanco and Austin 2006; Parton et al. 2007; Carrera et al. 2008). Our results may indicate that the higher turnover rates of root litters could be beneficial for maintaining soil nutrient availability and plant productivity for rangeland and grassland ecosystems in the arid and semiarid northern China because plants allocate more biomass belowground in such areas.

When litters with different chemistry and tissue structure decompose together, the chemical and physical decomposition environments are both altered (Kaneko and Salamanca 1999; Wardle et al. 2003). Nutrients such as $\mathrm{N}$ and $\mathrm{P}$ or inhibitory secondary compounds such as polyphenols might be transferred among different litter types by leaching and/or with the help of fungi (Salamanca et al. 1998). These alterations might 

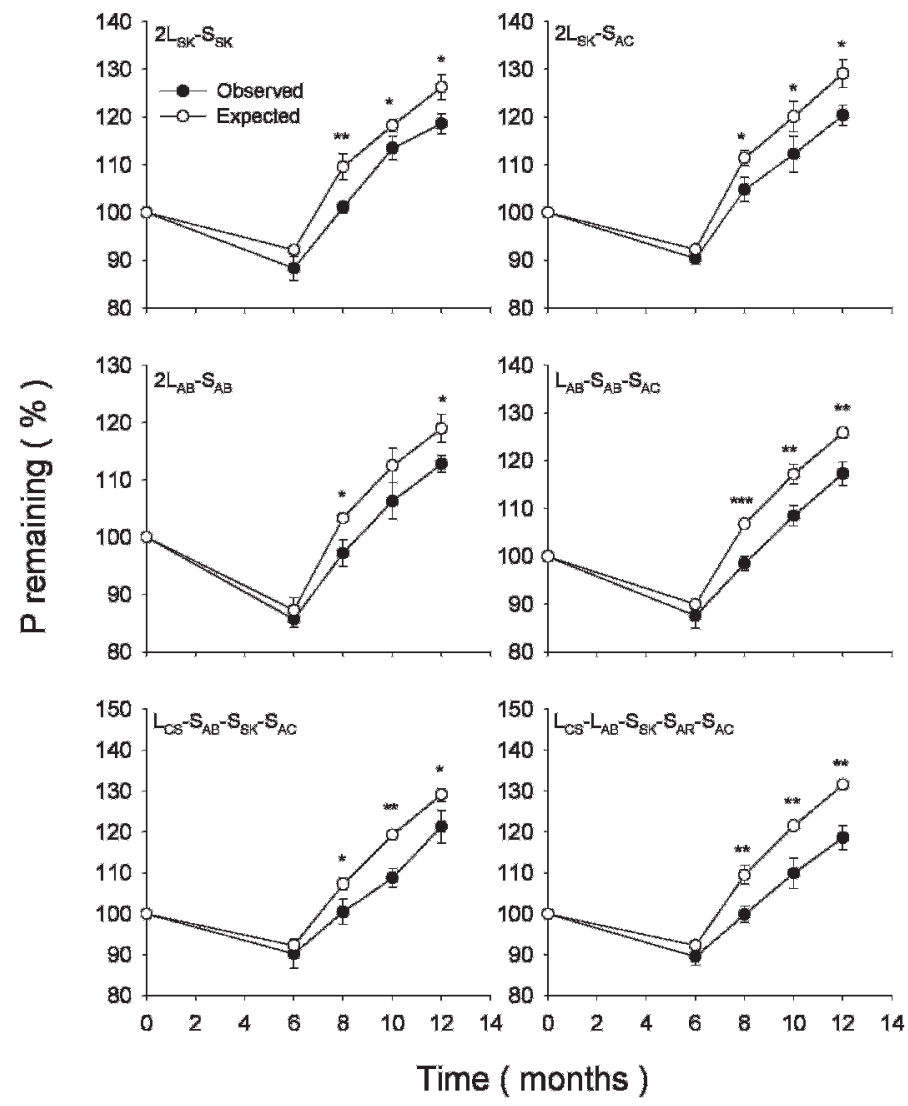

Figure 4. Comparisons of observed percentage of phosphorus (P) remaining in litter mixtures over time with expected percentage of $P$ remaining calculated from component pure litters. Vertical bars represent standard errors $(n=3)$. The Arabic numeral " 2 " before a litter type in the litter mixture combinations column denotes that two times the mass of that litter type was included in the mixture. Asterisks indicate significant differences between observed and expected values: ${ }^{\star} P<0.05$; ${ }^{\star \star} P<0.01$; ${ }^{* * *} P<0.001$. Species and litter codes are presented in Table 1.

also affect abundance and activities of decomposers (Hansen and Coleman 1998; Hansen 1999; Conn and Dighton 2000; Wardle et al. 2006). All these alterations might result in mixing effects during decomposition. However, contrary to our original hypothesis, not all litter mixtures can bring about mixing effects. In this study we found that mixing effects occurred only in six out of 11 litter mixture combinations, and it seemed that positive nonadditive effects generally occurred in the litter mixtures with more leaf than stem mass, whereas negative effects appeared in those litter mixtures with less leaf than stem mass. Our results also showed that with an increase in diversity of litter mixtures (from two to five) there was no obvious change in the mixing effects. Our results were in accordance with those reported by some previous studies (Wardle et al. 1997; Bardgett and Shine 1999; Ball et al. 2009) in that the characteristics of the added component litter species were more important to the patterns and directions of mixing effects than diversity per se. When a leaf litter with relatively higher level of nutrients (such as $\mathrm{N}$ and $\mathrm{P}$ ) mixed with a stem litter of relatively lower levels of nutrients, their overall decay rates tended to be accelerated. But with increasing proportion of the low-quality component of stem litters, the mixing effect was not as strong or did not occur at all.
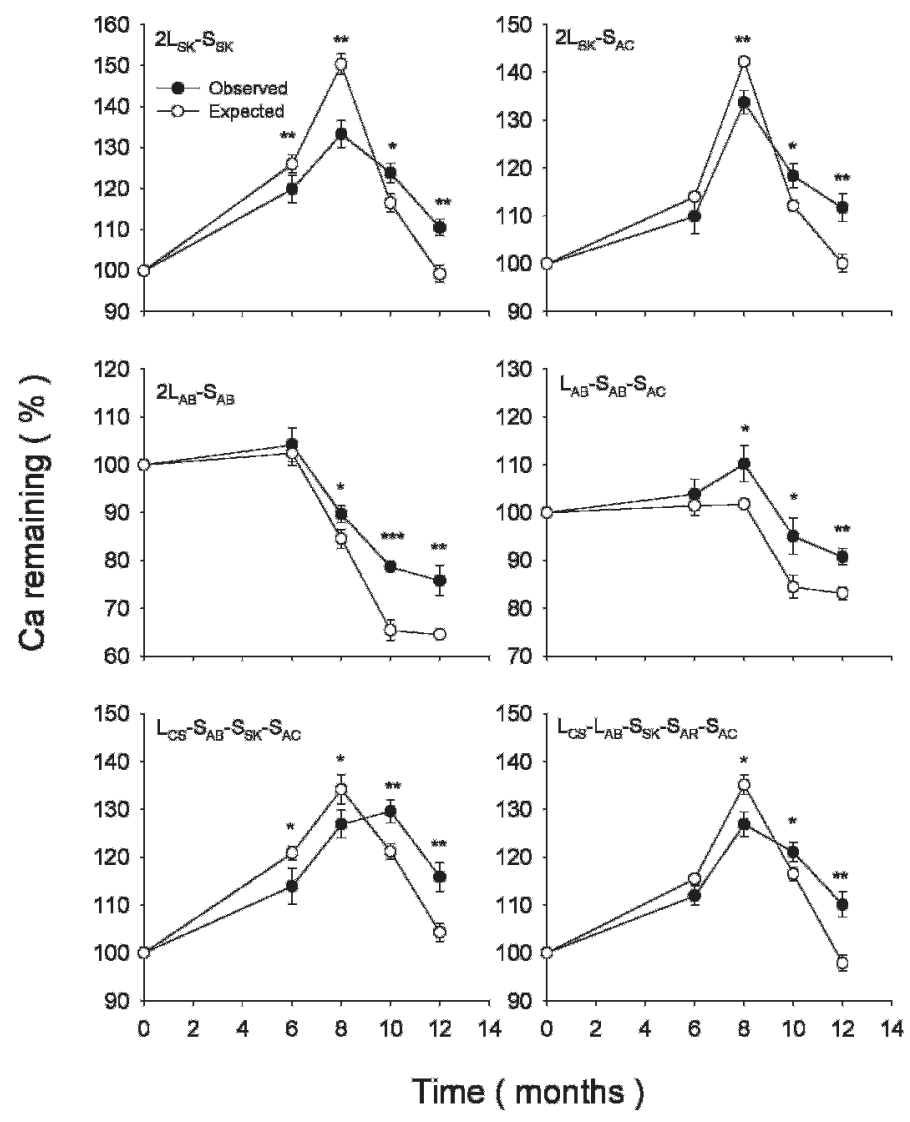

Time (months)

Figure 5. Comparisons of observed percentage of calcium (Ca) remaining in litter mixtures over time with expected percent of $\mathrm{Ca}$ remaining calculated from component pure litters. Vertical bars represent standard errors $(n=3)$. The Arabic numeral "2" before a litter type in the litter mixture combinations column denotes that two times the mass of that litter type was included in the mixture. Asterisks indicate significant differences between observed and expected values: ${ }^{*} P<0.05$; ${ }^{*} P<0.01$; ${ }^{* * *} P<0.001$. Species and litter codes are presented in Table 1.

We did not find any mixing effects in the two fine-root litter mixtures regardless of the level of similarity in the chemistry of component litters. This result differed from the study of Robinson et al. (1999) in which both positive and negative interactions occurred in root litter mixtures, although the chemistry between component root litters in that study was more similar than in ours. However, the differences between the observed and expected values in root litter mixtures shown in that study were relatively small. Unlike aboveground litters, root litters are less affected by leaching brought about by rain or snow and experience a relatively stable environment. The small or negligible mixing effects in root litters might also be caused by the overdominating effects of soil on the decomposition of buried litters and insensitivity of the belowground decomposer communities to the difference in nutrient availability and moisture.

Although litter mixing may have different effects (either positive or negative) on the decay rates of different litter mixture combinations, there is generally a similar negative effect on nutrient immobilization of litter mixtures by the end of first year of decomposition. The exact mechanism for this phenomenon is not clear. However, such effects may decrease the immobilization or facilitate the releases of some nutrients $(\mathrm{N}$, 


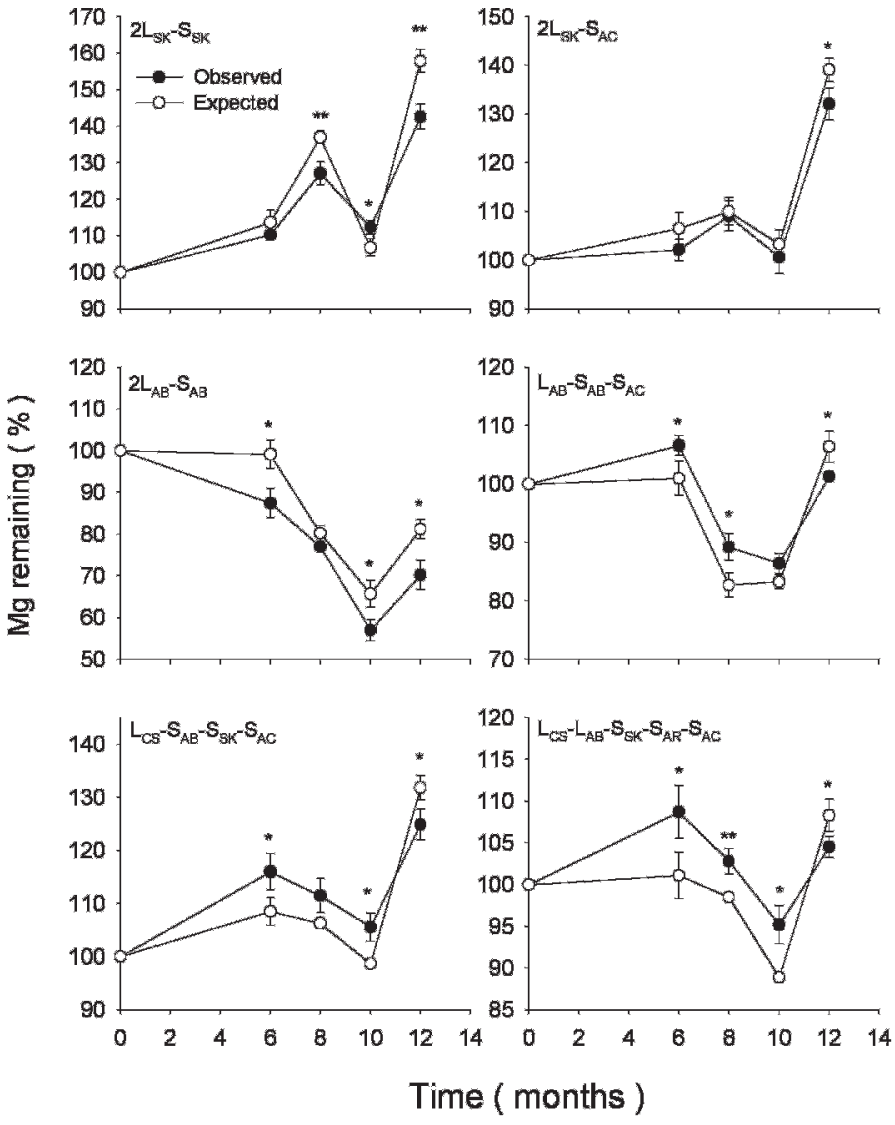

Figure 6. Comparisons of observed percentage of magnesium (Mg) remaining in litter mixtures over time with expected percentage of $\mathrm{Mg}$ remaining calculated from component pure litters. Vertical bars represent standard errors $(n=3)$. The Arabic numeral "2" before a litter type in the litter mixture combinations column denotes that two times the mass of that litter type was included in the mixture. Asterisks indicate significant differences between observed and expected values: ${ }^{\star} P<0.05 ;{ }^{* *} P<0.01 ;{ }^{* *} P<0.001$. Species and litter codes are presented in Table 1.

$\mathrm{P}, \mathrm{Ca}$, and $\mathrm{Mg}$ ) from litter mixtures relative to pure litter. Blair et al. (1990) found similar $\mathrm{N}$ fluxes in two leaf litter mixture combinations with lower $\mathrm{N}$ immobilization than predicted, although they found no mixing effects on decay rates. McTiernan et al. (1997) found that net $\mathrm{N}$ mineralization was hindered in four litter mixtures. Litter mixing may not actually increase nutrient availability over longer time periods, but may speed up the releases of nutrients during decomposition. The varying pattern of nutrient availability over time, especially of $\mathrm{N}$ and $\mathrm{P}$, could better match plant requirements or could favor some plant species over others (Hättenschwiler et al. 2005).

\section{IMPLICATIONS}

Mixing effects in litter decomposition only occurred in some litter mixture combinations in our study. Moreover, the direction of mixing effects depended on the properties of component litters and had no obvious correlations with litter diversity. Along with the altered decay rates of some litter mixtures, the immobilization of most nutrients was decreased. Change of plant species composition, such as occurs in most overgrazed rangeland systems, may alter mass loss rates, but may still facilitate the release of some nutrients through changing the timing of immobilization or nutrient release during litter decomposition depending on the amounts and chemical characteristics of litter produced in the new community. Our interpretations are limited to the first year of decomposition and a longer-term study would be needed to determine whether different litter mixtures influence long-term release of nutrient in these arid rangeland ecosystems. Our results also implicate that the cycling of nutrients, such as $\mathrm{N}$ and $\mathrm{P}$, may be altered significantly due to different litter mixtures with the change of plant species composition after rangeland degradation due to overgrazing in the arid and semiarid grassland of northern China.

\section{LITERATURE CITED}

AerTs, R. 1997. Climate, leaf litter chemistry and leaf litter decomposition in terrestrial ecosystems: a triangular relationship. Oikos 79:439-449.

Ball, B. A., M. A. Bradford, and M. D. Hunter. 2009. Nitrogen and phosphorus release from mixed litter layers is lower than predicted from single species decay. Ecosystems 12:87-110.

Ball, B. A., M. D. Hunter, J. S. Kominoski, C. M. Swan, and M. A. Bradford. 2008. Consequences of non-random species loss for decomposition dynamics: experimental evidence for additive and non-additive effects. Journal of Ecology 96:303-313.

Bardgett, R. D., and A. Shine. 1999. Linkages between plant litter diversity, soil microbial biomass and ecosystem function in temperate grasslands. Soil Biology and Biochemistry 31:317-321.

Blair, J. M., R. W. Parmelee, and M. H. Beare. 1990. Decay rates, nitrogen fluxes, and decomposer communities of single- and mixed-species foliar litter. Ecology 71:1976-1985.

BRIones, M. J. I., AND P. InESON. 1996. Decomposition of eucalyptus leaves in litter mixtures. Soil Biology and Biochemistry 28:1381-1388.

Carrera, A. L., M. B. Bertiller, and C. Larreguy. 2008. Leaf litterfall, fine-root production, and decomposition in shrublands with different canopy structure induced by grazing in the Patagonian Monte, Argentina. Plant and Soil311:39-50.

Chapman, K., J. B. WhittakeR, and 0. W. Heal. 1988. Metabolic and faunal activity in litters of tree mixtures compared with pure stands. Agriculture, Ecosystem and Environment 24:33-40.

Conn, C., and J. Dighton. 2000. Litter quality influences on decomposition, ectomycorrhizal community structure and mycorrhizal root surface and phosphatase activity. Soil Biology and Biochemistry 32:489-496.

EfFLAND, M. J. 1977. Modified procedure to determine acid insoluble lignin in wood and pulp. Technical Association of the Pulp and Paper Industry (TAPPI) 60:143-144.

Food and Agriculture Organization of the United Nations. 2006. World reference base for soil resources. Rome, Italy: Food and Agriculture Organization of the United Nations. 83 p.

Gartner, T. B., and Z. G. Cardon. 2004. Decomposition dynamics in mixed-species leaf litter. Oikos 104:230-246.

Gholz, H. L., D. A. Wedin, S. M. Smitherman, M. E. Harmon, and W. J. Parton. 2000. Long-term dynamics of pine and hardwood litter in contrasting environments: toward a global model of decomposition. Global Change Biology 6:751-765.

Giusman, A. J., H. F. Alarcón, and R. J. Thomas. 1997. Root decomposition in tropical grasses and legumes as affected by soil texture and season. Soil Biology and Biochemistry 29:1443-1450.

Hansen, R. A. 1999. Red oak litter promotes a microarthropod functional group that accelerates its decomposition. Plant and Soil 209:37-45.

Hansen, R. A., and D. C. Coleman. 1998. Litter complexity and composition are determinants of the diversity and species composition of oribatid mites (Acari: Oribatidae) in litterbags. Applied Soil Ecology 9:17-23. 
Hättenschwiler, S., A. V. Tiunov, and S. Scheu. 2005. Biodiversity and litter decomposition in terrestrial ecosystems. Annual Review of Ecology, Evolution, and Systematics 36:191-218.

НоввіЕ, S. E. 1996. Temperature and plant species control over litter decomposition in Alaskan tundra. Ecological Monographs 66:503-522.

Hooper, D. U., ANd P. M. Vitousek. 1997. The effects of plant composition and diversity on ecosystem processes. Science 277:1302-1305.

Kaneko, N., and E. F. Salamanca. 1999. Mixed leaf litter effects on decomposition rates and soil microarthropod communities in an oak-pine stand in Japan. Ecological Research 14:131-138.

$\mathrm{LI}$, Y. 1989. Impact of grazing on Aneurolepidium chinense steppe and Stipa grandis steppe. Acta Oecologica 10:31-46.

Liu, P., J. Huang, X. Han, O. J. Sun, and Z. Zhou. 2006. Differential responses of litter decomposition to increased soil nutrients and water between two contrasting grassland plant species of Inner Mongolia, China. Applied Soil Ecology 34:266-275.

Liu, P., J. Huang, L. Li, X. Han, and 0. J. Sun. 2007. Non-additive effects of litter mixtures on decomposition and correlation with initial litter $N$ and $P$ concentrations in grassland plant species of northern China. Biology and Fertility of Soils 44:211-216.

McTiernan, K. B., P. Ineson, And P. A. Coward. 1997. Respiration and nutrient release from tree litter mixtures. Oikos 78:527-538.

Meentemeyer, V. 1978. Macroclimate and lignin control of litter decomposition rates. Ecology 59:465-472.

Moretto, A. S., R. A. Distel, and N. G. Didoné. 2001. Decomposition and nutrient dynamic of leaf litter and roots from palatable and unpalatable grasses in a semi-arid grassland. Applied Soil Ecology 18:31-37.

Nelson, D. W., AND L. E. Sommers. 1996. Total carbon, organic carbon, and organic matter. In: D. L. Sparks, A. L. Page, P. A. Helmke, R. H. Loeppert, M. A. Soltanpour, M. A. Tabatabai, C. T. Johnston, and M. E. Sumner [EDs.]. Methods of soil analysis. Part 3, chemical methods. Madison, WI, USA: Soil Science Society of America, American Society of Agronomy. p. 961-1010.

OLSON, J. S. 1963. Energy storage and the balance of producers and decomposers in ecological systems. Ecology 44:322-331.
Ostertag, R., and S. E. Hobile. 1999. Early stages of root and leaf decomposition in Hawaiian forests: effects of nutrient availability. Oecologia 121:564-573.

Parton, W., W. L. Silver, I. C. Burke, L. Grassens, M. E. Harmon, W. S. Currie, J. Y. King, E. C. AdaiR, L. A. Brandt, S. C. Hart, and B. Fasth. 2007. Global-scale similarities in nitrogen release patterns during long-term decomposition. Science 315:361-364.

Robinson, C. H., J. B. Kirkham, and R. Littlewood. 1999. Decomposition of root mixtures from high arctic plants: a microcosm study. Soil Biology and Biochemistry 31:1101-1108.

Salamanca, E. F., N. Kaneko, and S. Katagiri. 1998. Effects of leaf litter mixtures on the decomposition of Quercus serrata and Pinus densiflora using field and laboratory microcosm methods. Ecological Engineering 10:53-73.

SEAStedt, T. R. 1988. Mass, nitrogen, and phosphorus dynamics in foliage and root detritus of tallgrass prairie. Ecology 69:59-65.

Seastedt, T. R., W. J. Parton, and D. S. OJima. 1992. Mass loss and nitrogen dynamics of decaying litter of grasslands: the apparent low nitrogen immobilization potential of root detritus. Canadian Journal of Botany 70:384-391.

Silver, W. L., and R. K. MiYa. 2001. Global patterns in root decomposition: comparisons of climate and litter quality effects. Oecologia 129:407-419.

TILman, D., AND J. A. Downing. 1994. Biodiversity and stability in grasslands. Nature 367:363-365.

Vivanco, L., And A. T. Austin. 2006. Intrinsic effects of species on leaf litter and root decomposition: a comparison of temperate grasses from North and South America. Oecologia 150:97-107.

Wardle, D., G. W. Yeates, G. M. Barker, and K. I. Bonner. 2006. The influence of plant litter diversity on decomposer abundance and diversity. Soil Biology and Biochemistry 38:1052-1062.

Wardle, D. A., K. I. Bonner, and K. S. Nicholson. 1997. Biodiversity and plant litter: experimental evidence which does not support the view that enhanced richness improves ecosystem functioning. Oikos 79:247-258.

Wardle, D. A., M. C. Nilsson, O. Zackrisson, and C. Gallet. 2003. Determinants of litter mixing effects in a Swedish boreal forest. Soil Biology and Biochemistry 35:827-835. 